\title{
PISMS: Parental Influence on Student Motivation and Self-esteem in Primary Education
}

\author{
Yaron Ghilay (Corresponding author) \\ The Neri Bloomfield School of Design and Education \\ Haifa, Israel \\ Tel: 972-54-468-8929Ｅ-mail: yghilay@gmail.com \\ Ruth Ghilay \\ Byalik School, Holon, Israel \\ Tel: 972-54-488-0628Ｅ-mail: ghilay@gmail.com
}

Received: Sep. 10, 2015 Accepted: Nov. 4, 2015 Published: November 4, 2015

http://dx.doi.org/10.5296/jse.v5i4.8510 URL: http://dx.doi.org/10.5296/jse.v5i4.8510

\begin{abstract}
The study presents a new model for primary education called PISMS (Parental Influence on Student Motivation and Self-esteem). Previous model named ISMS (Improving Student Motivation and Self-esteem) is designed to help schools foster motivation and self-esteem of students. PISMS is a complementary model because it allows schools to train parents how to become involved and to continue strengthening the mission of the school to improve students' motivation and self-esteem.

Parents who participated in a three-year study conducted in a primary school $(\mathrm{n}=73)$, reported that a course based on the principles of PISMS, was very helpful in strengthening their ability of how to improve their children's motivation and self-esteem. The significance of these findings is that an additional method for improving key variables having an essential impact on student learning, has been found.

The PISMS model has been found to be applicable to primary education, in particular, but it may be suitable for other schools as well.
\end{abstract}

Keywords: PISMS, ISMS, Parental involvement, Motivation, Self-esteem 


\section{Introduction}

\subsection{General Background}

Student motivation is a vital element that is required for high-quality education. Actually, learning cannot occur unless students are motivated consistently (Palmer, 2007). Another important variable that has an important impact on human behaviour is self-esteem (Baumeister, Campbell, Krueger \& Vohs, 2003). Evidence suggests that there are positive correlations between global self-esteem and academic performance (Khalid, 1990), self-confidence, success at schoolwork (Lawrence, 1996), and the successful functioning of the individual (Eden \& Hulbert, 1995). A conclusion that can be drawn from the research findings is that both motivation and self-esteem are essential variables having an influence on student learning.

ISMS (Improving Student Motivation and Self-esteem) is an existing model that allows creation of a course given to primary school students.

Ghilay \& Ghilay (2015) checked the effectiveness of ISMS by examining motivation and self-esteem of students, before and after their participation in a course based on the principles of ISMS. They found out that ISMS achieved the following significant improvements in motivation and self-esteem of students (scores are presented on a five point Likert scale):

Motivation: $\quad+5.05 \%\left(\right.$ pre-course $=3.9786$, post-course $\left.=4.1794, t_{(65)}=-2.663, p=.01\right)$.

Self-esteem: $\quad+7.31 \%\left(\right.$ pre-course $=3.9040$, post-course $\left.=4.1895, t_{(65)}=-3.234, p=.002\right)$.

To increase the performance of ISMS and achieve better improvements, the study introduces a complementary model called PISMS (Parental Influence on Student Motivation and Self-esteem). It is based on the idea of tightening the school connections with parents and persuading them to be partners who are committed to achieving this desirable goal.

According to the research literature, parental involvement has been regarded as a very important component of effective education during a long time (DES, 1967). Indeed, there is a great body of research pointing out that parental involvement is advantageous for children of all ages (Cox 2005; Desforges \& Abouchaar 2003; Epstein 2001; Hornby \& Rayleen, 2011). The literature distinguishes between two kinds of parental involvement: home-based such as supervision of homework and school-based, such as attending parent education workshops. The effectiveness of both kinds in improving academic achievement has been reported by several reviews (Fan \& Chen, 2001; Henderson \& Mapp, 2002; Jeynes 2005, 2007; Pomerantz, Moorman, \& Litwack, 2007). Other advantages include, better parent-teacher relationships, school climate, and increased parental satisfaction and interest in their children's education (Hornby \& Rayleen, 2011).

In spite of the benefits mentioned above, there are still gaps between what is presented in the literature and parental involvement practices existing at schools (Christenson \& Sheridan, 2001). Binns, Steinberg and Amorosi (1997) found out that in the U.S, 83\% of teachers considered that the level of parental involvement should be increased. Similar findings have 
been presented in the U.K by Williams, Williams and Ullman (2002).

There might be lots of reasons for the gap between what is said and what is done. It can be explained by the existence of different kinds of barriers, owing to diverse parents' attitudes, as follows:

- Lack of responsibility: parents who believe that it is not their responsibility to deal with their children's education, will not wish to be actively involved in either school-based or home-based parental involvement (Hoover-Dempsey \& Sandler, 1997). Thus, parents with a low level of belief in their ability to help their children are likely to avoid contact with schools because of their view that such involvement will not bring about positive outcomes for their children (Hoover-Dempsey \& Sandler, 1997).

- Lack of confidence: lack of confidence may also come from parents taking the view that they have not developed sufficient academic competence to effectively help their children. This view is more apparent as students progress through secondary schools and their academic work becomes more advanced (Eccles \& Harold 1993). Such views act as a barrier, despite widespread acknowledgement that the ability to support children's learning does not require a high level of education from parents (Clark, 1983; Hoover-Dempsey \& Sandler, 1997; Hornby, 2000).

- Fixed intelligence: there are parents who believe children's intelligence is fixed and that children's innate ability will set a limit on their achievement. Therefore, encouraging children to do their homework or make an effort is supposed to be a waste of time. Alternatively, parents who believe that achievement at school depends mainly on effort, and that children's abilities can always be developed, are more likely to be positive about parental involvement (Hornby \& Rayleen, 2011).

- Invitation for involvement: when parents think that their involvement is not valued by teachers or schools, they are less likely to get involved (Hoover-Dempsey \& Sandler, 1997). Therefore, parents' perceptions of invitations from schools are considered crucial in developing effective parental involvement (Epstein, 2001; Eccles \& Harold, 1993). On the other hand, schools which are welcoming to parents, develop more effective parental involvement.

\subsection{The new model}

The study introduces a new model for primary education called PISMS: Parental Influence on Student Motivation and Self-esteem. The model defines a comprehensive framework designed for training parents to become their children's coaches. After the training, parents should continue to increase and enhance the school's efforts focused on improving students' motivation and self-esteem, as presented in ISMS (Ghilay \& Ghilay, 2015).

According to the research literature, parental involvement is supposed to be a crucial factor, supporting the school for achieving significant educational goals (Cox 2005; DES, 1967; Desforges \& Abouchaar 2003; Epstein 2001; Hornby \& Rayleen, 2011). 
The main objective of PISMS is increasing and enhancing the previous process started by ISMS via linking parents and school goals and training them how to influence their children to improve their motivation and self-esteem. In doing so, PISMS intends to overcome the barriers that may prevent parental involvement, both at home and at school. The overall result of the two models when used together, can be much better than using the previous model only.

PISMS intends to achieve the following main objectives:

1. Changing parental attitudes to begin to understand that this is also their responsibility, not only of school, to deal with children's motivation and self-esteem.

2. Providing parents with practical and applicable tools to become their children's coaches, in order to achieve the desired mission.

PISMS intends to share with parents the following basic notions:

1. The previous ISMS model is based on the fundamental term "Architect," which is a metaphor for the creation of life success. It delivered children a central message that success in life in general and at school, in particular, depends mainly on the individual, and it requires meticulous pre-planning (Ghilay \& Ghilay, 2015). According to PISMS, it is crucial that the same exact message would be delivered to students by parents as well. The starting point is that both parents and the school are significant characters for the child and therefore, they have a common responsibility. Parents should transfer this message to their children because it is important for their success.

2. Without pre-planning, no architect plan would be carried out and meet the desired needs. Similar to an architect who pre-plans, anybody who wishes to succeed either in general life or at school, should pre-plan, determine a goal, strive for its achievement and pursue it. Parents should help the school to assimilate this attitude among students.

\subsubsection{General framework of the model}

The model is about to be undertaken in groups of up to sixteen parents during four meetings of three hours each (twelve hours overall). It is guided by an educational counsellor who has learned its principles and is based on the assumption that parents have a significant ability to influence on their children attitudes and behaviour. Therefore, parents can function as school change agents and help to strengthen student motivation and self-esteem.

The model is based on several characteristics and for each of them, parents should take part in different activities designated to demonstrate the main notions, as follows:

\section{Developing philosophy of being a "parent-coach":}

In order to be a parent-coach, parents should be aware of the fact that both they and the teachers are significant characters for providing students with emotional support. Such support might be helpful for their children's success. Parents should believe that they can achieve the following goals: 
- Nurturing a sense of competence: parents can suggest their children ways for nurturing a sense of capability, based on their own experience and the research literature.

- Belief in themselves: strengthening the belief in themselves and increasing their self-esteem.

- Students' motivation: strengthening students' motivation to succeed in life in general and at school, in particular.

- Encouraging students: parents should be aware of the significant importance of student encouragement. They should realize that encouragement is extremely helpful and can be easily implemented.

- An example of an appropriate activity: as an introduction, every parent is requested to present his/her view concerning being a coach of his child to become "an architect of my life".

2. Providing parents with practical tools for strengthening student motivation and self-esteem: a course based on PISMS principles, intends to provide parents with practical tools, designed to achieve the goals mentioned above, as follows:

a. Improving students' attitudes: parents are exposed to successful ways designed for improving students' attitudes and behaviour.

b. An example for an activity: the famous lecture of Levoy (2013), "When the Chips Are Down" might be an appropriate example. This recorded lecture features strategies for improving children's behaviour. Levoy (2013) shows how preventative discipline can anticipate many problems before they start. He explains how teachers and parents can create a stable, predictable environment in which children can flourish. After watching the central parts of the lecture, parents participate in a discussion focused on the main message, new insights gained, links to life cases and so on. The conclusion is that when children do not believe in themselves, their parents can intervene and become their promoters. Parents should look for the children's talents, find the areas in which they excel and nurture them.

c. Encouragement: parents should realize that encouragement is an essential working tool existing in their hands. It might be helpful for "touching the child's soil" and bring about the expected change. Dinkmeyer and Dreikurs (2000) stress the great importance of encouragement for children. It is a central tool for creation of positive self-esteem. Since encouragement is so essential, it would be good for parents to know what encouragement means and how to deal with it. Dreikurs and Soltz (1991) claim that children need encouragement like a plant needs water. Therefore, parents should encourage their children in order to help them to create a positive self-image enabling them to successfully face life missions. Thus, parents are exposed to the following principles of encouragement (Dinkmeyer \& Dreikurs, 2000): 
- Children acceptance: accept the child without any conditions. Every child/person is pretty good and deserves respect.

- Emphasizing the positive: emphasize the positive, namely, stress what exists rather than what is missing. Emphasize strengths rather than weaknesses, because they are a basis for growth and advancement.

- Avoidance of discouragement: avoid discouragement, contempt, humiliation or criticism. We should learn how to listen and accept the fact that there are differences in attitudes and perspectives among human beings.

- Separation of the deed from the doer: avoid stigmas that fix the situation and do not allow movement. Each failure shows a lack of skills and the courage to be imperfect is required for children as well.

- Recognition of efforts: recognize the effort and investment and not only the result. A student that has invested much effort, should be acknowledged, even if the final outcome in not perfect.

- Making mistakes: allowing children to make mistakes does not lead to praise, but can often be encouragement, for it displays trust in the child and provides opportunities for improvement.

- Gradual progress: even a small step forward might be significant. It is important to fix miles stones and to stress any advancement toward destination. We should enable ourselves and our kids to advance according to a personal rate.

- Praise versus encouragement: although there is heavy emphasis upon praise, it is imperative to note that encouragement and praise are not the same thing. Praise can be harmful if it focuses on the evaluation of the individual, leading the child to focus on the self and individual status. Encouragement directs attention away from self-glorification and toward the child's task, to learn.

Parents are exposed to different ways for creation of encouragement, such as:

- Creation of a significant dialogue and personal contact.

- Nonverbal encouragement: it can be undertaken by a view, a smile, an embrace, a kiss or everything focused on a positive attitude, nurturing close contact.

- A tone is important as well.

- Listening can promote encouragement by emotional ventilation.

- Presenting the kids motivational proverbs such as:

"People do not lack strength, they lack will" (Hugo, n.d.).

"Success is not achieved without labour" (Ibn Ezra, n.d.). 
The following are examples for activities focused on development of encouragement:

- Parents read the principles of encouragement and select one in order to give an example of being encouraged or encourage others.

- Parents are requested to describe in what life stages it is extremely important to encourage.

- Parents are requested to give examples for encouraging sentences strengthening children versus messages that can hurt them. Negative communication might include too high expectations, a comparison to other children or judicial criticism. Criticism should be informative avoiding determination of stigmas.

d. Talking with students in the same language as the school: because the school looks upon parents as active partners for the educational practice, it is crucial that both teachers and parents would talk with students in the same language. School explains to students the importance of motivation, perseverance and the belief in their ability. It also tries to convince them that they can overcome obstacles and reach achievements. It is important that the school and parents should deliver the same message: "Yes you can, yes you are capable". By combining forces and talking the same language, it is likely that students would succeed to fulfil their personal potential. Thus, it is crucial that parents, and not only the school, would make efforts to influence their children to be responsible for their studies, treat their studies respectfully and believe in themselves.

e. Creative thinking: in order to function as coaches, parents are often required to think in a different way compared to what they are used to. They should be able to help their children to be creative, especially in cases when they are stuck. Therefore, it is better not to emphasise their failures in difficult subjects such as Maths. On the contrary, parents should explain that success in challenging subjects is not mainly a matter of talent but it rather depends on exercising, persistence and motivation. A parent coach can help his/her child to exchange negative perceptions with positive attitudes in order to motivate him/her to make an effort.

f. An activity for example: presenting research results confirming the hypothesis that excelling is not a consequence of possessing innate gifts (Howe, Davidson \& Sloboda, 1998). Therefore, what is more important is to practice, persist and wish to succeed.

\section{Method}

\subsection{The study framework: evaluating the effectiveness of PISMS}

Parents of a primary school students (School A, n=73) who studied in a course based on the principles of PISMS, participated in a study intended to evaluate the course influence on their attitudes. The course was undertaken three times during the years 2013-14, 2014-15 and 2015-16. Parents' perceptions toward their ability to influence on their children's motivation and self-esteem were examined after the course ended. The significance of high scores might be that implementing the new model can improve the parental capability to influence their 
children's motivation and/or self-esteem. Such a result might have an important positive influence on students' future learning, in addition to the efforts made by the school for achieving that mission. Consequently, in the long run, students' achievements are likely to be better.

\subsection{The research question}

The research question intended to evaluate the effectiveness of the new PISMS model in primary schools. The model's effectiveness was measured relating to parents who finished a course based on PISMS. Their perceived ability to positively influence their children's motivation and self-esteem, has been measured.

The following research question was worded:

What effect does PISMS model have on parents of primary school students, concerning their perceived ability to improve their children's motivation and self-esteem?

\subsection{Population and Samples}

Population: the population addressed through the study included all parents at school A who took part in a course based on PISMS principles. School A is a primary school located in a city close to Tel-Aviv and it has six grades (from first to sixth). There are approximately 500 students overall and 35 teachers.

Samples: the study was based on the following three samples (each sample included two groups):

Sample 1: year 2013-14 - 20 parents.

Sample 2: year 2014-15 - 21 parents.

Sample 3: year 2015-16 - 32 parents.

Overall: 73 parents.

Parents were asked to answer the same questionnaire after participating in a course based on PISMS principles, during the three academic years mentioned above. The aim of the study was to measure their perceived ability to improve their children's motivation and self-esteem. The questionnaire was anonymous, and the rate of response was $100 \%$.

\subsection{Tools}

In order to answer the research question, a questionnaire, including 31 closed statements and two open ended questions was prepared. For each statement, respondents were requested to describe the degree by which their ability to positively influence their children has been improved, following the PISMS course. 
The responses were mentioned on the following five-point Likert scale:

1 Very little

2 Little

3 Medium

4 Much

5 Very much

The open-ended questions were designed to accomplish the main data gathered by the quantitative part of the questionnaire, as follows:

1. Describe if and how the course improved your insight that parental encouragement strengthens the children's feeling of capability, belief in themselves and motivation to succeed at school and in life.

2. Describe how you implement relating to your children, the principles of encouragement you have learned in the course.

\subsection{Data Analysis}

In order to examine the validity of the questionnaire, factors' reliability was calculated (Cronbach's alpha). Based on the reliability found, the following two factors were calculated:

1. Improving parental ability to influence students' motivation.

2. Improving parental ability to influence students' self-esteem.

For each factor, there was found a high value of reliability $(0.939,0.914$, respectively). Every factor has been determined by calculating the mean value of the items composing it.

Table 1 summarizes the two factors, the items composing them and the values of reliability. Each item presents a characteristic of the student. 
Table 1. Factors and reliability

\begin{tabular}{|c|c|}
\hline Factors & Questionnaire's questions (student characteristics) \\
\hline $\begin{array}{l}\text { Improving parental ability to } \\
\text { influence students' motivation }\end{array}$ & $\begin{array}{l}\text { Readiness to make an effort in order to succeed at school. } \\
\text { Willingness to study whatever taught at class. } \\
\text { Wish to have good marks. }\end{array}$ \\
\hline Alpha $=0.939$ & $\begin{array}{l}\text { Striving to learn from his/her mistakes even though he/she fails in } \\
\text { an exam. } \\
\text { Understanding the importance of studying at school. } \\
\text { Wish to succeed at the school. } \\
\text { Readiness to prepare before every test. } \\
\text { Striving to prepare homework properly. } \\
\text { Readiness to learn even though the lesson is boring. } \\
\text { Willingness to concentrate during lessons. } \\
\text { Understanding that success at school depends on willingness. } \\
\text { Readiness to take responsibility in order to succeed at school. } \\
\text { Readiness to fix goals in order to make progress at school. } \\
\text { The ability to execute plans that will be beneficial to progress at } \\
\text { school. } \\
\text { Willingness to make an effort in order to understand what the } \\
\text { teacher explains. } \\
\text { Willingness to make an effort until success is reached. } \\
\text { Readiness to invest time in order to succeed at school. } \\
\text { Concern to carry out assignments. } \\
\text { Readiness to make an effort in order to succeed at school. } \\
\text { Readiness to continue making effort even in a case of failure. } \\
\text { Readiness to continue making effort even if he/she does not succeed } \\
\text { in a certain subject. } \\
\text { The ability to think creatively in order to overcome difficulties at } \\
\text { the school. } \\
\text { The ability to find creative solutions when he/she does not succeed } \\
\text { in a certain subject. }\end{array}$ \\
\hline $\begin{array}{l}\text { Improving parental ability to } \\
\text { influence students' self-esteem } \\
\text { Alpha }=0.914\end{array}$ & $\begin{array}{l}\text { Self-perception as a good student. } \\
\text { Self-evaluation as having talent to succeed at school. } \\
\text { Self-evaluation as having knowledge and understanding in lots of } \\
\text { areas. } \\
\text { Self-evaluation as capable of succeeding at school. } \\
\text { Self-evaluation that he/she succeeds to face the learning challenges. } \\
\text { Self-evaluation as being able to properly deal with time } \\
\text { management. } \\
\text { Belief that the teachers appreciate him/her. } \\
\text { Belief that he/she is able to succeed at school. }\end{array}$ \\
\hline
\end{tabular}

For each factor, a mean score was calculated (including standard deviation). The following statistical tests have been undertaken as well $(\alpha<=0.05)$ :

1. ANOVA (Analysis of Variance): in order to check significant differences of factors' means between the three years (2013-14, 2014-15 and 2015-16).

2. Paired Samples T-test: it was conducted for checking significant differences between the two factors.

\section{Results}

There were no significant differences between the years 2013-14, 2014-15 and 2015-16 
concerning the mean scores of both factors (Analysis of Variance, $\alpha \leq 0.05$ ).

It means that there was a replication of the results found in the first year (2013-14) also in the second (2014-15) and the third (2015-16). It strengthens the findings and gives them more validity. Therefore, table 2 presents the mean factors' scores for all the three years together (including Analysis of Variance showing that there were no significant differences between the three years).

Table 2. Factors' mean scores, Standard Deviation and Analysis of Variance results

\begin{tabular}{|l|c|c|c|c|}
\hline Factor & $\mathrm{N}$ & Mean & Std. Deviation & Analysis of Variance \\
\hline $\begin{array}{l}\text { Improving parental ability to influence } \\
\text { students' motivation }\end{array}$ & 73 & 4.33 & .47 & $F_{(2,70)}=1.541, p=.221$ \\
\hline $\begin{array}{l}\text { Improving parental ability to influence } \\
\text { students' self-esteem }\end{array}$ & 73 & 4.47 & .68 & $F_{(2,70)}=1.037, p=.360$ \\
\hline
\end{tabular}

Table 2 introduces the following findings:

Relating to both factors, parents claim that their ability to influence their children has been significantly improved. Both factors are rated with tremendously high scores $(4.33,4.47$, respectively). Moreover, there is a significant difference between these factors

(Paired Samples T-test, $\left.t_{(72)}=-4.516, p=.000\right)$.

The meaning of these findings is that a course based on PISMS, has a positive impact on improving parental ability to influence students' motivation and self-esteem. Moreover, parents' influence on students' self-esteem is significantly higher (as mentioned above, the difference between 4.47 and 4.33 is statistically significant).

The open-ended questions strengthen the closed statements as shown in the following quotes (school A):

2013-14:

"The course strengthened and encouraged me to look at things from the perspective of my child, especially after the lecture that dealt with poker chips. It gave me an insight into something that I have never been aware of. I finally realized the great importance of encouraging my child and the need to always find positive words to say. After the course, I have become more patient and attentive to my child."

"I have learned that encouragement from parents reinforces the child's confidence, his belief in himself and his abilities. During his stay at school, he is experiencing successes but sometimes also disappointment and frustration. We should address each of these situations and encourage the child."

"Following the course, I try to empower every child's success by encouraging and strengthening. I try to give him a sense that failure is not the end of the world and from a low point, it is possible just to grow." 
"We tend to discuss with our children test results, dictations, reports, and so on and explore how we can improve them, what mistakes were made, and how it can be leveraged to deepen their understanding of the subject matter."

2014-15:

"Following the course, I learned to encourage our children to do more using positive words. We started encouraging them that they are always capable of more, and of course it gave great results. The first lesson in which we observed the poker chips' lecture, influenced me greatly. I began to apply this approach by using positive words and encouragement and it is really helpful. The course was a real success for me and for my children. Thank you very much."

"I came to the course with curiosity and a desire to strengthen my knowledge and way of functioning as a parent. I got a lot of new insights transferred in an interesting and engaging way. I adopted a lot of new points of view and I am truly confident that I behave differently with my kids, on a daily basis. Many thanks for the planning and the effective implementation of the course."

"The course was a gift of life for me. Short, focused and including solutions, unlike ongoing treatments that last infinite time and do not reach any solution. Thanks to the course I am a better person and a better mother. You gave me a lot of strength."

2015-16:

"I use to implement everything I have learned in the course, on a daily basis. It significantly stressed my insight that encouraging children, considerably strengthen them."

"Following the course, I think a lot of times before I dare to insult my child, I count till 10, take a deep breath and remember the words of encouragement I have studied at the course."

"After the course, even if I come home nervous from work, I do my best to find free time and be attentive for my child, showing him that I am aware of him."

"The course extremely strengthened my insight that encouragement is tremendously important and it has a direct influence on student success at the school and in the external social environment. The course is adequate for my children's age, it is focused and includes lots of examples, helping parents to practically implement theoretical principles dealing with student motivation and self-esteem."

The quotes mentioned above stress the very important contribution of the PISMS course to primary school students. It significantly improved their parents' way of thinking and their ability to positively influence their children's motivation and self-esteem. Parents learned to believe they have a significant impact on their children's behaviour and way of thinking. Such a conceptual change in parents' attitudes may have a substantial influence on their children, leading them to better achievements at school, in particular, and in life in general. 


\section{Discussion}

According to the study's results, the PISMS model was found to be practical and successful for improving parents' ability to influence on their children's motivation and self-esteem. This conclusion is based on two constituents:

1. Quantitative part (questionnaire's closed questions): parents have rated with high scores both factors examined: improving parental ability to influence students' motivation and their ability to influence children's self-esteem. This achievement was reached during a short period of time: a twelve hour course based on the PISMS model. Besides, the same results received in the first year of the study (2013-14), repeated in the second (2014-15) and the third year (2015-16) as well.

2. Qualitative part (questionnaire's open-ended questions): additional detailed evidence was achieved by the qualitative part of the research. According to parents' verbal responses, the model was found to be very helpful and effective for strengthening their ability to help their children and encourage them. It had a substantial contribution for improving their belief and knowledge required for continuing and strengthening the school efforts directed at improving students' motivation and self-esteem. Furthermore, following the course, parents became supporters and change agents of the school, understanding that the school cannot face such challenges alone.

The repetition of the quantitative results during three years and the mix of both methods (quantitative and qualitative), substantially strengthen the validity of the study.

The significance of such findings is that it is quite feasible to link parents to the school efforts, focusing on improving key variables having vital influence on student learning and academic performance (Christophel, 1999; Elliott, Hufton, Willis \& Illushin, 2005; Fredricks, Blumenfeld \& Paris, 2004; Khalid, 1990; Lepper, Greene \& Nisbett, 1973; Reeve, 2006). Moreover, such a change might be undertaken within a primary school framework without external assistance or additional substantial expenditure.

\section{Conclusion}

The study examined three cohorts of courses based on PISMS. The quantitative and qualitative findings show that participants perceived it as a very effective tool for changing their attitudes and knowledge. Consequently, parents reported that even their daily behaviour toward their children has been improved.

According to the study's findings, PISMS is applicable for training parents whose children learn particularly in primary schools. However, it might be suitable for other kinds of schools as well, such as junior-high or high schools.

As mentioned earlier, the new model deals mainly with training parents to become change agents of the school. In order to assimilate such a change at schools, counsellors and teachers should be trained for acquiring relevant knowledge required to parents' training. The success of such a process is entirely dependent on the school staff qualifications and the belief that such a model can thoroughly change parents' knowledge and their ways of thinking. 
Because PISMS has been found to be effective, it is recommended to adopt it in additional schools and to conduct a follow-up research. The next study can include more schools and parents and is expected to give additional validity to the model.

\section{References}

Baumeister, R. F., Campbell, J. D., Krueger, J. I., \& Vohs, K. D. (2003). Does high self-esteem cause better performance, interpersonal success, happiness, or healthier lifestyles? Psychological Science in the Public Interest, 4(1), 1-44. http://dx.doi.org/10.1111/1529-1006.01431

Binns, K., Steinberg, A. \& Amorosi, S. (1997). The Metropolitan Life survey of the American teacher: Building family-school partnerships: Views of teachers and students. New York: Lewis Harris and Associates.

Christenson, S.L., \& Sheridan. S.M. (2001). Schools and families: Creating essential connections for learning. New York: Guilford Press.

Christophel, D.M. (1990). The relationship among teacher immediacy behaviours, student motivation and learning. Communication Education, 39(4), 323-340. http://dx.doi.org/10.1080/03634529009378813

Clark, R. (1983). Family life and school achievement: Why poor black children succeed or fail. Chicago, IL: University of Chicago Press.

Cox, D. D. (2005). Evidence-based interventions using home-school collaboration. School Psychology Quarterly, 20(4), 473-497. http://dx.doi.org/10.1521/scpq.2005.20.4.473

DES (Department of Education and Science). (1967). Children and their primary schools, the Plowden report. London: HMSO.

Desforges, C. \& Abouchaar, A. (2003). The impact of parental involvement, parental support and family education on pupil achievement and adjustment: Research report 433. London: Department for Education and Skills.

Dreikurs, R. \& Soltz, V. (1991). Children: The challenge, New-York: Plume.

Dinkmeyer, D. \& Deikurs, R. (2000), Encouraging children to learn, New-York: Routledge, Taylor \& Francis Group.

Eccles, J.S. \& Harold. R.D. (1993). Parent-school involvement during the early adolescent years. Teachers College Record, 94(3), 568-587.

Eden, C., \& Hulbert, W. (1995). Gender and IT in the primary classroom: Building confidence through laptops. Computer Education, 81, 10-14.

Elliott, J.G., Hufton, N.R., Willis, W., \& Illushin, L. (2005). Motivational, engagement and educational performance: International perspectives on the context of learning. New York: Palgrave Macmillan.

Epstein, J. L. (2001). School, family and community partnerships. Boulder, CO: Westview 
Press.

Fan, X. \& Chen. M. (2001). Parent involvement and students' academic achievement: A meta-analysis. Educational Psychology Review, 13(1), 1-22. http://dx.doi.org/10.1023/A:1009048817385

Fredricks, J.A., Blumenfeld, P.C., \& Paris, A.H. (2004). School engagement: Potential of the concept, state of the evidence. Review of Educational Research, 74(1), 59-109. http://dx.doi.org/10.3102/00346543074001059

Ghilay, Y. \& Ghilay, R. (2015). ISMS: A new model for improving student motivation and self-esteem in primary education. International Electronic Journal of Elementary Education, 7(3), 383-398.

Henderson, A.T. \& Mapp. K.L. (2002.) A new wave of evidence: The impact of school, family and community connections on student achievement. Austin, TX: Southwest Educational Development Laboratory.

Hoover-Dempsey, K.V. \& Sandler. H.M. (1997). Why do parents become involved in their children's education? Review of Educational Research, 67(1), 3-42. http://dx.doi.org/10.3102/00346543067001003

Hornby, G. (2000). Improving parental involvement. London: Cassell.

Hornby, G. \& Rayleen, L. (2011). Barriers to parental involvement in education: An explanatory model, Educational Review, 63(1), 37-52. http://dx.doi.org/10.1080/00131911.2010.488049

Howe, M. J. A., Davidson J. W. \& Sloboda, J. A. (1998). Innate talents: Reality or myth. Behavioural and Brain Sciences, 21(3), 399-407. http://dx.doi.org/10.1017/S0140525X9800123X

Hugo, V. (n.d.). BrainyQuote.com. Retrieved August 5, 2014, from http://www.brainyquote.com/quotes/quotes/v/victorhugo378733.html

Ibn-Ezra, M. (n.d.). Among Quotation Marks. Retrieved August 5, 2014, from http://www.pitgam.net/quote/1631/1/ (in Hebrew).

Jeynes, W.H. (2005). A meta-analysis of the relation of parental involvement to urban elementary school student academic achievement. Urban Education, 40(3), 237-269. http://dx.doi.org/10.1177/0042085905274540

Jeynes, W.H. (2007). The relation between parental involvement and urban secondary school student academic achievement: A meta-analysis. Urban Education, 42(1), 82-110. http://dx.doi.org/10.1177/0042085906293818

Khalid, R (1990). Self-esteem and academic achievement: An investigation of ethnic and sex differences. Journal of Behavioural Sciences, 1(1), 3-17.

Lawrence, D. (1996). Enhancing self-esteem in the classroom. London: Paul Chapman. 
Lepper, M.R., Greene, D. \& Nisbett, R.E. (1973). Undermining children's intrinsic interest with extrinsic reward: A test of the over-justification effect. Journal of Personality and Social Psychology, 28(1), 129-137. http://dx.doi.org/10.1037/h0035519

Levoy, R. (2013). When The Chips Are Down - Poker Chips [Motion picture]. YouTube.

Palmer, D. (2007). What Is the Best Way to Motivate Students in Science? Teaching Science-The Journal of the Australian Science Teachers Association, 53(1), 38-42.

Pomerantz, E.M., Moorman, E.A. \& Litwack. S.D. (2007). The how, whom and why of parents' involvement in children's academic lives: More is not always better. Review of Educational Research, 77(3), 373-410. http://dx.doi.org/10.3102/003465430305567

Reeve, J. (2006). Teachers as facilitators: What autonomy-supportive teachers do and why their students benefit. The Elementary School Journal, 106(3), 225-236.

Williams, B., Williams, J. \& Ullman. A. (2002). Parental involvement in education: Research report 332. London: Department for Education and Skills.

\section{Copyright Disclaimer}

Copyright for this article is retained by the author(s), with first publication rights granted to the journal.

This is an open-access article distributed under the terms and conditions of the Creative Commons Attribution license (http://creativecommons.org/licenses/by/3.0/). 